Génét. Sél. Evol., 1983, 15 (4), 495-500

\title{
An attempt to modify allelic frequencies at the Adh locus of a Drosophila melanogaster population in a tropical environment
}

\author{
J.R. DAVID \\ Laboratoire de Biologie et Génétique évolutives du C.N.R.S. \\ F 91190 Gif-sur-Yvette
}

\begin{abstract}
Summary
One thousand laboratory-reared adults, homozygous for the $A d h \mathrm{~F}$ allele of the alcohol dehydrogenase locus, were released in a tropical environment harboring a natural population in which the frequency of the $F$ allele was very low (about $2 \mathrm{p}$. 100). During and after release, bananas were provided to prevent rapid dispersal of the adult flies and to obtain their progeny. Samples of this population were studied for Adh genotype frequencies. As a consequence of matings between released and native flies, the number of heterozygous flies increased significantly after one generation. However, $F$ allele frequency returned to its initial level after two generations, suggesting a strong selective disadvantage of the heterozygotes.
\end{abstract}

Key words : Drosophila melanogaster, climatic adaptation, Adh locus, balancing selection.

\section{Résumé}

Tentative de modification des fréquences alléliques au locus Adh dans une population de Drosophila melanogaster en milieu tropical

Un millier d'adultes élevés au laboratoire et homozygotes pour l'allèle $A d h^{\mathrm{F}}$ ont été relâchés dans un environnement tropical qui abritait déjà une population naturelle ayant une fréquence très faible de cet allèle (environ 2 p. 100). Pendant l'expérience, des bananes ont été disposées en permanence afin de fixer la population et d'obtenir une descendance. Des échantillons de cette population ont ensuite été étudiés. Après une génération, un accroissement significatif des hétérozygotes a été observé, montrant le croisement entre les mouches indigènes et les mouches relâchées. Mais la fréquence de l'allèle $F$ est revenue à son niveau initial après deux générations, suggérant un désavantage sélectif des hétérozygotes. librante.

Mots clés : Drosophila melanogaster, adaptation climatique, locus Adh, sélection équi- 


\section{Introduction}

In relation to the cosmopolitan status of Drosophila melanogaster, there is a large amount of genetic divergence between its allopatric populations. Especially interesting are the differences between tropical and temperate populations since it has been repeatedly argued that they reflect genetic adaptations to different environmental conditions (DAvid \& BocQueT, 1975 ; David et al., 1977). Temperate (European) and tropical (African) populations can be distinguished by their alozyme frequencies, greatest divergence occurring at the $A d h$ (acohol dehydrogenase) locus : in Europe, the frequency of the $F$ allele is about 96 p. 100 while it is less than 5 p. 100 in tropical Africa (David, 1982).

This locus is particularly interesting since many investigators have tried to determine if its polymorphism is maintained by selective pressure (CLARKE, 1975 ; DAVID, 1977 ; OAKESHOTT et al., 1982). All experiments to this end, however, have been done in artificial laboratory conditions and generally by supplying a large amount of alcohol to the cultures. The aim of the present study was to check the hypothesis of balanced polymorphism in a natural environment. A large number of flies genetically marked by a rare biochemical allele was released in a small, isolated natural population in tropical Africa. Surprisingly, only a slight, short-term modification was observed; the significance of the data has been discussed.

\section{Methods}

The experiment was done on the campus of the University of Calavi near Cotonou (R.P. Bénin). A previous study had shown that only two species were attracted by banana baits in buildings; among these, $D$. melanogaster adults represented more than 95 p. 100 of the total catch, indicating that adults of this species are attracted by human constructions, while most other wild living species are repelled by such buildings (see DAvid, 1979 for details). On the other hand, the University of Calavi is in the country, $12 \mathrm{~km}$ from Cotonou, and may be considered as a kind of ecological island for $D$. melanogaster populations.

Prior to the experiment, banana baits were put in the building of the department of Zoology and flies were regularly collected for one week. This provided about 500 adults, confirming the presence of a natural, although probably small, population. No larval breeding sites were discovered in the surroundings.

The released flies, native to the Congo, belonged to two strains homozygous for the $A d h^{\mathrm{F}}$ allele. It was supposed that such flies with an African genetic background would have a better chance to establish in a tropical environment. Due to the extraction of the $F$ allele, both strains were inbred; they were crossed before the experiment in order to improve their viability. The genotypes of the collected flies were assessed after starch gel electrophoresis and $\mathrm{ADH}$ activity was stained by the usual procedure, using isopropanol as a substrate. 


\section{Results}

About 1000 genitically-marked adults were released over a week in the close vicinity of the banana baits. Prior to release, a sample of native flies was taken to determine the allelic frequencies in the natural population. Another sample was taken at the end of release. During the following weeks, new bananas were regularly added in order to settle the population and to increase its number. Numerous larvae were observed and many adults emerged. Samples of this population were collected every two weeks; these intervals corresponded to approximately one generation since the ambiant average temperature was close to $25^{\circ} \mathrm{C}$.

Results are given in table 1 and variations of the frequency of the $F$ allele and of heterozygous flies are shown in figure 1.

\section{TABLE 1}

Frequencies of Adh (alcohol dehydrogenase) genotypes and alleles before and after the release of 1000 flies homozygous for the $F$ allele.

Fréquences des génotypes et des allèles du locus Adh

avant et après le lâcher d'un millier de mouches homozygotes pour l'allèle $F$.

\begin{tabular}{|c|c|c|c|c|c|c|}
\hline \multirow{2}{*}{ Sample condition } & \multirow{2}{*}{$\mathrm{N}^{\circ}$} & \multicolumn{3}{|c|}{ Genotype } & \multirow{2}{*}{$\mathbf{N}$} & \multirow{2}{*}{$\begin{array}{c}\text { Percen- } \\
\text { tage } \\
\mathbf{F}\end{array}$} \\
\hline & & FF & FS & SS & & \\
\hline Before release & 1 & 0 & 5 & 120 & 125 & 2.0 \\
\hline End of release & 2 & 13 & 4 & 77 & 94 & 16.0 \\
\hline 2 weeks after & 3 & 5 & 18 & 94 & 117 & 11.8 \\
\hline 4 weeks after ... & 4 & 0 & 4 & 95 & 99 & 2.0 \\
\hline 6 weeks after. & 5 & 0 & 2 & 105 & 107 & 0.9 \\
\hline
\end{tabular}

$\mathrm{N}$ : Number of adults studied - Nombre d'adultes étudiés.

$\mathrm{F}: A d h \mathrm{~F}$.

$\mathrm{S}: A d h \mathrm{~S}$.

As is usual in trop:cal Africa, the $F$ allele was rare in the indigenous population and only heterozygous adults were found. At the end of the period of release, the collected sample was very far from a Hardy-Weinberg equilibrium $\left(\chi^{2}=62.7\right.$ : $\mathrm{p}<0.001$ ). Due to the time schedule, we must admit that the $13 \mathrm{FF}$ homozygotes collected at the end of release corresponded to introduced flies while the FS heterozygotes still belonged to the original population. Pooling the heterozygote data of these first two samples provided a more precise estimate of the frequency of the $F$ allele $(3.5$ p. 100$)$ in the initial population.

The third sample, taken two weeks later, was closer to H.W. equilibrium $\left(\chi^{2}=8.9\right.$; $\mathrm{p}<0.02$ ). The 5 FF flies observed corresponded either to old released individuals 


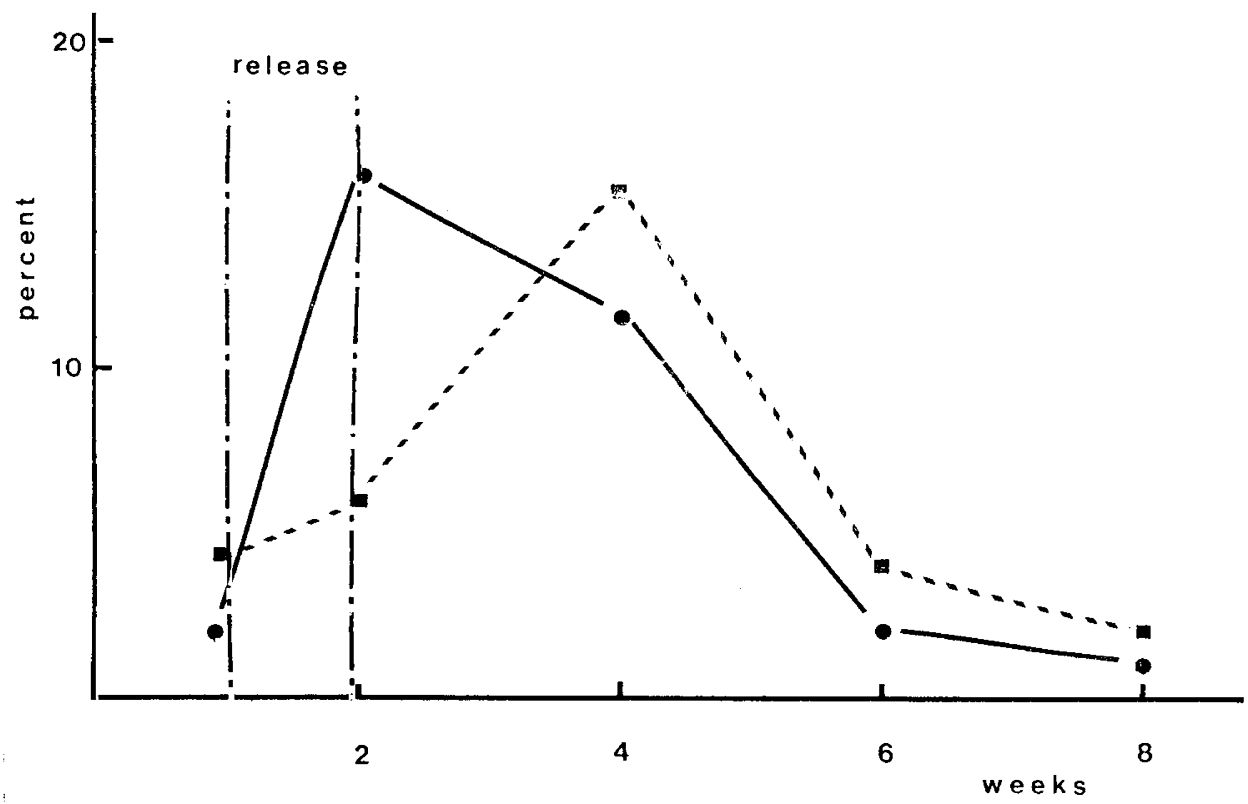

FIG, 1

Variation of the frequencies of $\mathrm{Adh}^{F}$ allele $(\bullet)$ and of heterozygous flies $(\bullet)$ before, during and after the release of flies homozygous for the $F$ allele.

Variation de la fréquence de l'allèle $\operatorname{Adh} F(\bullet)$ et de celle des hétérozygotes (®) avant, pendant et après le lâcher de mouches homozygotes pour l'allèle $F$.

or to their direct progeny. The occurrence of 15 p. 100 heterozygous flies was more interesting. Compared to the previous samples, this one showed a significant increase $\left(\chi^{2}=12.8 ; \mathrm{p}<0.01\right)$, probably due to the progeny of crosses between native and released flies.

In the last two samples (second and third generations), FF flies disappeared and the proportion of the $F$ allele was back at its initial level. The frequency (1.5 p. 100) was even lower than at the beginning but the difference was not significant.

\section{Discussion}

A first surprising observation in this study is the low proportion of geneticallymarked flies collected in the second sample at the end of the release period, in spite of the apparently favorable conditions for their establishment. A possible explanation is to assume that released flies were simply diluted by an indigenous population of greater size. Since the sample taken just after the release contained about 15 p. 100 of FF flies, the effective number should have been around 6500 . In ecological studies, 


\section{I.N.R.A. - C.N.R.Z. \\ Département de Génétique Animés \\ BIBLLOTHEQUE Animat

the size of natural insect populations is extremely difficult to estimate (BEGoN, 1979). As argued above, direct observation in the present case suggested that this size was much less. For example, at the time of collection, less than 200 adults were present on the baits. We may thus assume that a significant part of the released flies was lost.

A part of the released flies was able to produce progeny and to mate with indigenous individuals, as suggested by the genotype frequencies of the third sample. This was, however, a transient phenomenon, disappearing in the next generation. Again two explanations may be considered : (1) massive arrival of indigenous flies or (2) elimination of the introduced $F$ allele by some selective disadvantage. Since no spectacular increase of the population was noticed, the second hypothesis seems more likely. However, this does not imply that the $A d h$ locus itself was the target of selection. A more plausible interpretation is that, after crossing, some kind of genetic breakdown occurred, causing low fitness in the heterozygous flies.

Obviously, the experiment described here would have to be repeated several times in various conditions before more precise conclusions could be drawn. For example, the possible dilution of the released fl:es by the indigenous population could be checked by collecting samples at shorter time intervals. Also, the survival of the released flies could be studied in an enclosed population. Presently available observations illustrate the difficulty, but also the usefulness, of experimenting under natural conditions. The release of artificially-grown insects bearing some genetic defects appears to be a fascinating potential technique for biological pest control (WHITTEN \& FosTER, 1975). Results with Drosophila however show that much remains to be learned in this field and that a gene may be eliminated even when it does not produce, per se, a genetic load.

Received January 24, 1983.

Accepted June 17, 1983.

\section{Acknowledgements}

I wish to thank C. Tossou for help during the experiment and Mrs M. DE SCHEEMAEKer-Louis and E. PLA for performing the electrophoresis.

\section{References}

BEGON M., 1979. Investigating animal abundance. Edw. Arnold, London, 97 p.

Clarke B., 1975. The contribution of ecological genetics to evolutionary theory : detecting the direct effect of natural selection on particular polymorphic loci. Genetics, 79, 101-113.

David J.R., 1977. Signification d'un polymorphisme enzymatique : la déshydrogénase alcoolique chez Drosophila melanogaster. Année Biol., 16, 451-472.

DAVID J.R., 1979. Attractive behaviour toward human constructions helps to explain the domestic and cosmopolitan status of some drosophilids. Experientia, 35, 1436-1437. 
DaVID J.R., 1982. Latitudinal variability of Drosophila melanogaster : allozyme frequencies divergence between European and Afrotropical populations. Biochem. Genet., 20, 747-761.

DaVid J.R., BocQuet C., 1975. Similarities and differences in the latitudinal adaptation of two Drosophila sibling species. Nature, 257, 588-590.

David J., Boceuet C., De ScheemaecKer-Louis M., 1977. Genetic latitudinal adaptation of Drosophila melanogaster : new discriminative biometrical traits between European and equatorial African populations. Genet. Res. Camb., 30, 247-255.

OAKESHOTT J.G., GiBSON J.B., 1981. Is there selection by environmental ethanol on the alcohol deshydrogenase locus in Drosophila melanogaster? In : Genetic studies of Drosophila pepulations, ed. by J.B. Gibson and J.G. OAkeshotT, Aus. Univ. Press, Canberra, pp: 103-120.

Whitten M.J., Foster G.G., 1975. Genetical methods for pest control. Annu. Rev. Entomol., 20, 461-476. 